\title{
The Effects of Intervention Based on the Trans-Theoretical Model on Physical Activity and Metabolic Control of Diabetic Women
}

\author{
Trans-Teorik Model Bazında Müdahalenin Diyabetik Kadınların Fiziksel Aktivitesi ve Metabolik Kontrolü \\ Üzerine Etkileri
}

Rabiollah Farmanbar ${ }^{1}$, Maryam Zavar Moghadam², Saeed Omidi ${ }^{1}$, Abolhassan Afkar $^{1}$

${ }^{1}$ Social Determinants of Health Research Center (SCHRC), Guilan University of Medical Sciences, Rasht, Iran

2 Department of Health Education and Health Education, Health School, Guilan University of Medical Sciences, Rasht, Iran

\section{ABSTRACT}

Background: Prevention and treatment of diabetes have an economic burden for the society. Treatment of diabetes is accompanied by the willingness of the patients to control their diabetes. This study aimed to show the effects of intervention based on the transtheoretical model on physical activity and metabolic control of diabetic women.

Methods: This was a randomized control trial study which conducted on 98 diabetics women (48: intervention and 50: control) in two health centers in Qazvin, Iran. Patients of each center were placed in intervention group and control group randomly. Data collection tool was a questionnaire, consisting of demographic characteristics, the determination of physical activity (GPAQ) and a questionnaire about TTM constructs in physical activity behavior. The $\mathrm{HbA1c}$ determined by blood test. Educational intervention design based on the results of the questionnaire and data analysis and then implemented to the intervention group. Data related to post-test collected three months after the end of the intervention and then measured the HbA1c level. Data analyzed using SPSS software version 19.

Results: There was no a significant difference before intervention in demographic variables, the amount of physical activity, HbA1c and constructs model in both groups. There was a significant difference after intervention in the mean constructs model of intervention group than control group $(P<0.05)$. Moreover, there was a significant difference in the mean physical activity of intervention group than control group. While there was no a significant difference in $\mathrm{HbA1c}$ level in both groups.

Conclusion: Transtheoretical model-based intervention required more consideration in increasing physical activity in chronic diseases. The implementation of similar interventions with more sample size is a necessity in both genders.

Key Words: Trans-theoretical, physical activity, metabolic control, diabetic women

Accepted: 01.26.2018
Received: 08.13 .2018

\section{ÖZET}

Amaç: Diyabetin önlenmesi ve tedavisi toplum için ekonomik bir yüke sahiptir. Diyabet tedavisine hastaların diyabetlerini kontrol etme istekleri eşlik eder. Bu çalışmada, transteorik modele dayanan müdahalenin diyabetik kadınların fiziksel aktivitesi ve metabolik kontrolü üzerindeki etkileri gösterildi.

Yöntemler: Bu çalışma, İran'ın Qazvin kentindeki iki sağlık merkezinde 98 diyabet hastası kadın üzerinde (48: müdahale ve 50: kontrol) yapılan randomize kontrollü bir araştırmaydı. Her merkezin hastaları müdahale grubuna ve kontrol grubuna rastgele yerleştirildi. Veri toplama aracı, demografik özelliklerden, fiziksel aktivitenin (GPAQ) belirlenmesinden ve fiziksel aktivite davranışındaki TTM yapılarıyla ilgili bir anketten oluşmuştur. $\mathrm{HbA1c}$ kan testi ile belirlenmiştir. Eğitimsel müdahale tasarımı, anket ve veri analizinin sonuçlarına dayanmakla beraber daha sonra müdahale grubuna da uygulandı. Son test ile ilgili veriler, müdahalenin sona ermesinden üç ay sonra toplanmış ve daha sonra HbA1c seviyesini ölçmüştür. Veriler SPSS yazılımı versiyon 19 kullanılarak analiz edildi.

Bulgular: Her iki grupta demografik değişkenlere, fiziksel aktivite miktarına, HbA1c ve yapı modeline müdahale etmeden önce anlamlı bir fark yoktu. Müdahale grubunun ortalama yapı modelinde müdahale sonrası kontrol grubundan anlamlı bir farklılık vardı $(P<0,05)$. Ayrıca, müdahale grubunun ortalama fiziksel aktivitesinde kontrol grubundan anlamlı bir farklılık vardı. Her iki grupta da HbA1c düzeyinde anlamlı bir fark yoktu.

Sonuç: Transteorik model tabanlı müdahale, kronik hastalıklarda fiziksel aktivitenin arttırılmasında daha fazla dikkat gerektirmiştir. Daha fazla örneklem büyüklüğü ile benzer müdahalelerin uygulanması her iki cinsiyette de bir zorunluluktur.

Anahtar Sözcükler: Trans-teorik, fiziksel aktivite, metabolik kontrol, diyabetik kadınlar

Geliş Tarihi: 26.01 .2018

Kabul Tarihi: 13.08.2018

Address for Correspondence / Yazışma Adresi: Abolhassan Afkar, Social Determinants of Health Research Center (SCHRC), Guilan University of Medical Sciences, Rasht, Iran E-mail: Afkar@gums.ac.ir

CTelif Hakkı 2019 Gazi Üniversitesi Tıp Fakültesi - Makale metnine http://medicaljournal.gazi.edu.tr/ web adresinden ulaşılabilir.

CC Copyright 2019 by Gazi University Medical Faculty - Available on-line at web site http://medicaljournal.gazi.edu.tr/

doi:http://dx.doi.org/10.12996/gmj.2019.35 


\section{INTRODUCTION}

Diabetes is one of the most important metabolic disorders and major health problems and costly for both patients and health systems (1). In 2011 World Health Organization (WHO) statistics have shown that nearly 346 million diabetics lived in the world over which continuing the current treatment trend and prevention of this disease, the number will double by 2030 (1). Diabetes prevalence was more than \%14 in individuals over the age of 30 years in Iran in 2015(2). Today, the positive effects of regular physical activity on community health and its role in control and prevention of many diseases such as diabetes have been confirmed. (3). Despite the fact that the advantages of physical activity in control and the management of type 2 diabetes have been proved. Although, numerous studies have shown that more than $80 \%$ of diabetics are insufficiently physically active(4). The decreasing of physical activity increases insulin resistance as the main factor in the progression of type 2 diabetes. In a study which conducted on noninsulin-dependent diabetic women in Isfahan, Iran, researchers found that \%90 of diabetic women did not have enough physical activity in their free time(5). However, the time for housekeeping activities in Iranian women was more in comparison with that of American women, but $99.3 \%$ of housekeeping activities of diabetic women were light and very light $(6,7)$. $\mathrm{HbA} 1 \mathrm{c}$ is an appropriate indicator for evaluation of the average of blood sugar and the best therapeutic target for treatment of diabetics is the adjustment of $\mathrm{HbA} 1 \mathrm{c}(8)$. Each $1 \%$ reduction in $\mathrm{HbA} 1 \mathrm{c}$ decreases the risk of type 2 diabetes by $35 \%$. One of the major factors of failure in $\mathrm{HbA} 1 \mathrm{c}$ control is the lack of awareness and knowledge among patients. change behavior is a continues process and consists of some distinct stages that reflect personal and cognitive characteristics of the target $\operatorname{group}(2,9)$.

Transtheoretical model (TTM) provides a set of logical and regular steps of decision making to patients behavior change (10) and confirmed that change does not occur instantaneously, rather change is a gradual and stepwise process and each individual has psychological readiness to change (11). This model is mostly used in studying detriments of behavioral and is commonly used in studies regarding nutrition and dietary including fat intake and weight management. TTM is composed of four constructs: Stage of change (SOC) as a person attempts to change a behavior, he or she moves through five stages: pre-contemplation (Has no intention of taking action within the next six months), contemplation (Intends to take action in the next six months), preparation (Intends to take action within the next thirty days and has taken some behavioral steps in this direction), action(Has changed behavior for less than six months), and maintenance(Has changed behavior for more than six months ) (12). Processes of change are composed of activities and strategies which assist in one to progress in SOC and consist of two main stages: first, a cognitive process which is related to the thinking and individuals' feeling about unhealthy behavior, second, Processes of behavioral which leads to change in unhealthy behavior (13). In this model, the balance between the perceived benefits of adopting a new behavior and its barriers or losses to adopting new behavior is called decisional balance. When the advantages exceed the disadvantages, movement from passive stages of pre-contemplation, contemplation, and preparation is expected towards active stages or implementation and maintenance (14). Self-efficacy is defined as a person's perceived confidence in his or her ability to deal with barriers to initiating and maintaining behavioral change (15).

Given the high prevalence of diabetes and its economic and health consequences in Iran, the importance of prevention by focusing on identification of factors affecting on diabetes, also low physical activity in diabetics and considering the role of physical activity in diabetes, the objective of this study was to determine the effects of TTM in physical activity on $\mathrm{HbA} 1 \mathrm{c}$ in patients with type two diabetes in Qazvin, Iran.

\section{MATERIAL and METHODS}

This was a randomized control trial study which conducted in diabetes screenings program of health centers of Qazvin, Iran. The program conducted in two centers, one center was selected randomly as the control center and another was selected as the case. After listing the name of each patient with type 2 diabetes, random sampling conducted based on inclusion and exclusion criteria. Finally, 48 and 50 patients were selected as case group and control group, respectively. Data collection tool was a questionnaire consisting of three parts. The first part was included demographic characteristics like age, gender, education status, marital status, job status and duration of diabetes. The second part was included TTM-based model consisting of stages of change for physical activity (a five dimension localized algorithm), change processes, self-efficacy and localized decisional balance of physical activity questionnaires. The third part was included Global Physical Activity Questionnaire (GPAQ) $(16,17)$. Thirty dimensions for change processes, six dimensions for self-efficacy and ten dimensions for decisional balance were designed in five-point Likert forms (18). The evaluation of $\mathrm{HbA1c}$ conducted two months before and three months after intervention based on previous studies.

\section{Training process}

The training program consists of four stages of training intervention during four weeks, each stage conducted for 50-60 minutes. Educational contents were designed according to the Transtheoretical model and based on ten change processes. Increasing the individuals' awareness, the disadvantages of lack of physical activity and the advantages of doing it, restatement of individuals' positive experience on exercise in the past, using verbal persuasion, introducing successful individuals among diabetic women community in physical activity and the level of HbA1c control as model, divided goals into help to increasing the self-efficacy about doing physical activity and statement of participants ' experience in each session were used in educational program. Finally, a training package was given to intervention group including pamphlet, folder, training $C D$ about exercise in diabetics. Moreover, During the three months after intervention, text messages about the importance of physical activity were sent to patients and their families.

\section{Statistical analysis}

Data analysis was performed using SPSS software version 19. After assessing the normality of data, statistical tests were used for data estimate. The significance level was $\mathrm{p}<0.05$. in the control group without any educational intervention, pretest and then test were taken after three months. Then, educational packages were given to control group.

\section{RESULTS}

The results of this study showed that there was no a significant difference in demographic variables among two groups of participants $(P=0.00)$. The mean (SD) age of patients was $47.07 \pm 6.2$. $92.85 \%$ were married. $76.53 \%$ of participants were under diploma. The majority of participants were housekeeper (89.79\%) and $66.32 \%$ were suffered from diabetes less than 5 years.

Table 1 shows the results of comparing physical activity in stages of change in both before and after intervention groups. Changes in physical activity stages in before and after results could be indicated as the effects of the intervention.

Table 1: Comparing physical activity stages of change in intervention and control groups before and after the intervention.

\begin{tabular}{|c|c|c|c|c|c|c|c|c|}
\hline \multirow[t]{2}{*}{ Stages of change } & \multicolumn{2}{|c|}{$\begin{array}{l}\text { Intervention } \\
\text { Group(before) }\end{array}$} & \multicolumn{2}{|c|}{$\begin{array}{l}\text { Intervention } \\
\text { Group(after) }\end{array}$} & \multicolumn{2}{|c|}{$\begin{array}{l}\text { Control } \\
\text { Group( before) }\end{array}$} & \multicolumn{2}{|c|}{$\begin{array}{l}\text { Control } \\
\text { Group( after) }\end{array}$} \\
\hline & $\begin{array}{l}\text { frequen } \\
\text { cy }\end{array}$ & $\begin{array}{l}\text { Percentag } \\
\text { e }\end{array}$ & frequency & $\begin{array}{l}\text { Percentag } \\
\text { e }\end{array}$ & frequency & $\begin{array}{l}\text { Percentag } \\
\text { e }\end{array}$ & frequency & $\begin{array}{l}\text { Percentag } \\
\text { e }\end{array}$ \\
\hline \multirow{5}{*}{$\begin{array}{l}\text { precontemplation } \\
\text { contemplation } \\
\text { preparation } \\
\text { action } \\
\text { maintenance }\end{array}$} & 18 & 37.5 & - & - & 15 & 30 & 6 & 15.4 \\
\hline & 11 & 22.9 & 8 & 19.5 & 17 & 34 & 12 & 30.8 \\
\hline & 5 & 10.4 & 9 & 22 & 11 & 20 & 12 & 30.8 \\
\hline & 1 & 2.1 & 9 & 22 & 2 & 4 & 6 & 15.7 \\
\hline & 13 & 27.1 & 15 & 36.6 & 6 & 12 & 3 & 7.7 \\
\hline Total & 48 & 100 & 41 & 100 & 50 & 100 & 39 & 100 \\
\hline
\end{tabular}


In addition, the results of statistical tests showed a significant difference in Trans theoretical model constructs in both intervention and control groups after educational intervention Table 2 . The mean scores of the construct in cognitive and behavioral processes of change, self-efficacy and decisional balance after an educational intervention in the intervention group increased in comparison with control group $(p<0.05)$.
Comparing the constructs surface of the process of change in both intervention and control groups after the end of intervention showed that the difference in the intervention group was significant compared with control group. However, the difference in the increasing level of awareness and dramatic relief was not significant.

Table 2: Comparison between the Trans theoretical model constructs (self-efficacy, decisional balance, and the process of change) on the patients in the intervention group after receiving the treatment

\begin{tabular}{llllll}
\hline Application model & Intervention & & control & & $\begin{array}{l}\text { Independent } \\
\text { T-Test }\end{array}$ \\
& Mean & SD & Mean & SD & 0.025 \\
\hline Self-efficacy & 13.80 & 4.82 & 11.38 & 4.10 & 0.000 \\
$\begin{array}{l}\text { Decisional balance } \\
\text { Process of change }\end{array}$ & 13.43 & 5.8 & 9.87 & 4.8 & 0.000
\end{tabular}

In subconstruct, the balance construct in decisional, the advantages of the intervention group was significant than the control group, but after the end of the intervention, there was no a difference in the disadvantages of doing physical activity in subconstruct. The frequency distribution of physical activity behavior showed that the majority of participants in both before and after the intervention had moderate physical activity.
Before the intervention, there was no a significant difference among two groups $(P>0.05)$. While, after the end of the intervention the difference among two groups was significant $(P<0.05)$ Table 3 . After the intervention, there was no a significant difference in the mean $\mathrm{HbA1c}$ of intervention group than control group $(\mathrm{P}>0.05)$.

Table 3: Comparison of the mean of $\mathrm{HbA1c}$ and physical activities between two groups, once before and three months after receiving the treatment.

\begin{tabular}{lllllll}
\hline variable & Period & \multicolumn{2}{l}{ Intervention group } & \multicolumn{2}{c}{ Control group } & Independent \\
& & mean & SD & mean & SD & T-Test \\
\hline HbA1c & Before intervention & 7.97 & 1.40 & 7.77 & 1.40 & 0.55 \\
& After intervention & 7.20 & 1.33 & 7.30 & 1.37 & 0.77 \\
Physical & Before intervention & 2114 & 1878 & 1798 & 1771 & 0.394 \\
activity & After intervention & 2296 & 1643 & 1444 & 970 & 0.006 \\
\hline
\end{tabular}

\section{DISCUSSION}

This study aimed at the effectiveness of an intervention based on Transtheoretical model in increasing the physical activity and metabolic control in diabetic women. According to the findings of the study, intervention based on Transtheoretical model increases physical activity and constructs score of TTM, but did not have any effects on metabolic control.

The construct of change stages is based on the principle that education is able to improve the individual's progression in change stages (19). According to the results, the number of individuals who were in operating stages in the intervention group increased from $18.7 \%$ before intervention to $45.5 \%$ after intervention. While in control group, the number of individuals decreased from $12 \%$ before intervention to $7.7 \%$ after intervention. These results indicate that intervention had a positive effect in improvement of progression in the change stages of physical activity behavior in the intervention group. Similar results were found in Jaliliyan, et al. Eskandari et al, Findroff et al and Solhi et al (20-23).

The change processes use for help to movement in change stages and divided into two groups: behavioral and cognitive processes. According to the Trans-Theoretical model, by the progression of individuals in change stages, the level of cognitive and behavioral process increase, so that individuals used more cognitive processes in pre-operative stages and used cognitive processes in operating stages. An incremental progress is observed in both behavioral and cognitive processes in the intervention group. This improvement is seen more cognitive before receiving the treatment by the patients, whereas it is seen more in behavior while being affected by the treatment.

According to the result of this study, after the educational intervention, the mean construct score of change processes increased significantly in the intervention group than control group. The rate of utilization of all levels except for the increase of awareness and dramatic relief increased in the intervention group increased than the control group. Moeini et al, Lipkke et al, Calaghan et al and Farmanbar et al found similar results $(16,19,24,25)$. In addition, the intervention had a positive effect on self-efficacy of physical activity and decisional balance which the results were similar to Hashemi et al, and Solhi et al, studies $(9,23)$. Introducing successful models, dividing tasks into smaller tasks, objective examples and practical exercises of physical activity in the home environment were the strategies used in the increasing of physical activity in the intervention group.
Before the intervention doing physical activity in both groups was in the average level which after the intervention found a significant difference in the intervention group than control group. Hashemi et al and Moeini et al and Farmanbar et al also found similar results $(9,16,19)$.

However, in the study by Shojaeizadeh et al. Reusch et al and Dutton et al, there was no change in the improvement of physical activity after the Transtheoretical model-based intervention (26-28).

After the end of the intervention in metabolic control, there was no a significant difference in the $\mathrm{HbA} 1 \mathrm{c}$ of the intervention group compared with control group. Nonetheless, changes were significant than before. Aghamolaei et al, Heisler et al, Kim et al and Rezayi et al found a significant increase in the level of glycogen hemoglobin after intervention (29-32). Rosenbek et al found that the amount of glycogen hemoglobin changed in case group as well as control one after intervention (33).

Diabetes control is depended on the patient's effort. According to the results of this study, it can be included that education of diabetics based on Trans Theoretical model is useful for increasing the self-efficacy of patients. The results of this study showed that the more comprehensive training by increasing the physical activities in long term may be effective in controlling diabetes.

\section{CONCLUSIONS}

Educational intervention based on Trans theoretical model had an impact on constructs of Trans theoretical Model and physical activity behavior, whereas did not effect on metabolic control in diabetic patients.

Patients in the intervention group reported significant improvements in selfefficacy; they also perceived significantly fewer cons to physical activity than their standard care counterparts.

Three of ten change processes were also shown to be used significantly more by patients in the intervention group. Although the study had a small sample size, it expanded the base of research in this area, as there are fewer studies about the Transtheoretical Model in intervention trials for diabetes control. Trends from the analysis indicated that these variables can be influenced, though the program necessitates further exploration, as it is not yet clear whether the increase in these variables will lead to increased $\mathrm{HbA} 1 \mathrm{C}$ and metabolic control. 


\section{Acknowledgments}

This study derived from MSc thesis of health education and supported by Guilan University of Medical Sciences, Rasht, Iran. Special thanks to all contributors.

\section{Conflict of interest}

No conflict of interest was declared by the authors.

\section{REFERENCES}

1.Group NDD. Classification and diagnosis of diabetes mellitus and other categories of glucose intolerance. Diabetes. 1979;28:1039-57.

2. Esteghamati A, Gouya MM, Abbasi M, Delavari A, Alikhani S, Alaedini F, et al. Prevalence of diabetes and impaired fasting glucose in the adult population of Iran: National Survey of Risk Factors for Non-Communicable Diseases of Iran. Diabetes care. 2008;31:96-8.

3.Rabiollah Farmanbar, Isa Mohammadi Zeidi, Abolhassan Afkar. Effect of Theory-Based Individual Counseling on Physical Activity and Glycemic Control in Patients with Type 2 Diabetes Mellitus: A Quasi-Experimental Study. Iran Red Crescent Medical Journal. 2018 ;20: :e64581.

4. Health Do, USA HS. Promoting health, preventing disease: Objectives for the nation: Department of Health and Human Services; 1980.

5. Forghani B, Kasaeyan N, Faghih Imani B, Hossein Pour M, Amini M. The assessment of physical activity in non-insulin dependent diabetic women reffered to Endocrine \& Metabolism Research Center. Iranian Journal of Endocrinology and Metabolism. 2000;2:169-73.

6.Afkhami-Ardekani M, Rashidi M. Iron status in women with and without gestational diabetes mellitus. Journal of Diabetes and its Complications. 2009;23:194-8.

7.Ganji F, Reisi R, Khosravi S, Kasiri K, Jafarzadeh L, Zahedi M, et al. Effect of a participatory intervention to reduce the number of unnecessary cesarean sections performed in Shahrekord, Iran. Journal of Shahrekord Uuniversity of Medical Sciences. 2006;8.

8. Amini M, Mehr Mohamadi N, Aminoroaya A. Incidence of type 2 diabetes in 25-75 years without diabetes symptom refered to Diabetes Research Center in Isfahan, during 1997-2002. Journal of Zanjan University of Medical Science. 2003;12:33-40.

9. Hashemi SZ, Rakhshani F, Navidian A, Mosavi SR. Effectiveness of educational program based on Trans-Theoretical model on rate of physical activity among household women in Zahedan, Iran. 2013.

10.Butler JT. Principles of health education and health promotion: Morton Publishing Company; 1994.

11.Glanz K, Rimer BK, Viswanath K. Health behavior and health education: theory, research, and practice: John Wiley \& Sons; 2008.

12.Flath SC, Cardinal BJ. Cross-cultural comparison of college students' physical activity behavior in the Republic of China and United States of America on the basis of the transtheoretical model. Weight loss, exercise and health research. 2006:153-78

13.Lee YM. Process of change, decisional balance and self efficacy corresponding to stages of change in exercise behaviors in middle aged women. Journal of Korean Academy of Nursing. 2004;34:362-71.

14. Wakui S, Shimomitsu T, Odagiri $Y$, Inoue S. Relation of the stages of change for exercise behaviors, self-efficacy, decisional-balance, and dietrelated psycho-behavioral factors in young Japanese women. Journal of Sports Medicine and Physical Fitness. 2002;42:224.

15.Bandura A. Perceived self-efficacy in cognitive development and functioning. Educational psychologist. 1993;28:117-48.

16. Farmanbar R, Akhoondi M, Afkar A, Bakhshi F. Factors associated with physical activity in ringleaders of righteous of guilan medical society basij organization: Applying the transtheoretical model. Journal of Military Medicine. 2017;19:422-9.

17. Mahmoudi A. Effects of self care planning on reduction of $A 1 C$ hemoglobin in adults with diabetes mellitus. Medical Science Journal of Islamic Azad Univesity-Tehran Medical Branch. 2006;16:171-6.
Trans-theoretical model on diabetic women

18. Hazavehei M, Khani Jyhouni A, Hasanzadeh A, Rashidi M. The effect of educational program based on BASNEF model on diabetic (Type II) eyes care in Kazemi's clinic,(Shiraz). Iranian Journal of Endocrinology and Metabolism. 2008;10:145-54.

19.Moeini B, Jalilian M, Hazavehei SMM, moghim BA. Promoting physical activity in type 2 diabetic patients: A theory-based intervention. 2012.

20.Jalilian M, Darabi M, Sharifirad G, Kakaei H. Effectiveness of interventional program based on trans-theoretical model to promote regular physical activity in office workers. J Health Syst Res. 2012.

21.Eskandari N, Araban M, Saki Malehi A. Promoting physical activity in women referred to health centers applying the trans-theoretical model. Iranian Journal of Health Education and Health Promotion. 2015;3:14-22.

22.Findorff MJ, Hatch Stock H, Gross CR, Wyman JF. Does the transtheoretical model (TTM) explain exercise behavior in a communitybased sample of older women? Journal of aging and health. 2007;19:9851003.

23.Solhi M, Ahmadi L, Taghdisi MH, Haghani H. The Effect of Trans Theoretical Model (TTM) on exercise behavior in pregnant women referred to dehaghan rural health center in. Iranian Journal of Medical Education. 2012;11:942-50.

24.Lippke S, Ziegelmann JP, Schwarzer R, Velicer WF. Validity of stage assessment in the adoption and maintenance of physical activity and fruit and vegetable consumption. Health Psychology. 2009;28:183.

25.Callaghan $P$, Khalil E, Morres I. A prospective evaluation of the Transtheoretical Model of Change applied to exercise in young people. International journal of nursing studies. 2010;47:3-12.

26.Shojaeezadeh D, Tol A, Sharifirad G, Alhani F. Effect of education program based on empowerment model in promoting self-care among type 2 diabetic patients in Isfahan. Razi Journal of Medical Sciences. 2013;20:18-31.

27.Reusch A, Ströbl V, Ellgring $H$, Faller $H$. Effectiveness of small-group interactive education vs. lecture-based information-only programs on motivation to change and lifestyle behaviours. A prospective controlled trial of rehabilitation inpatients. Patient Education and counseling. 2011;82:18692.

28.Dutton GR, Provost BC, Tan F, Smith D. A tailored print-based physical activity intervention for patients with type 2 diabetes. Preventive medicine. 2008;47:409-11.

29.Aghamolaei T, Eftekhar H, Mohammad K, Sobhani A, Shojaeizadeh D, Nakhjavani $\mathrm{M}$, et al. Influence of educational intervention using interaction approach on behavior change, hemoglobin AIC and Health-related quality of life in diabetic patients. Journal of School of Public Health and Institute of Public Health Research. 2005;3:1-2.

30. Heisler M, Smith DM, Hayward RA, Krein SL, Kerr EA. How well do patients' assessments of their diabetes self-management correlate with actual glycemic control and receipt of recommended diabetes services? Diabetes care. 2003;26:738-43.

31.Kim C-J, Hwang A-R, Yoo J-S. The impact of a stage-matched intervention to promote exercise behavior in participants with type 2 diabetes. International journal of nursing studies. 2004;41:833-41.

32.Rezaei N, Tahbaz F, Kimyagar M, AlaviMajd H. The effect of nutrition education on knowledge, attitude and practice of type 1 diabetic patients from Aligoodarz. Journal of Shahrekord Uuniversity of Medical Sciences. $2006 ; 8$.

33.Minet LR, Wagner L, Lønvig E, Hjelmborg J, Henriksen J. The effect of motivational interviewing on glycaemic control and perceived competence of diabetes self-management in patients with type 1 and type 2 diabetes mellitus after attending a group education programme: a randomised controlled trial. Diabetologia. 2011;54:1620-9. 